\title{
US technology support under the microscope
}

Washington. The Advanced Technology Program (ATP) - - the programme closest to the heart of the Clinton administration's science and technology policy - went on trial this week, with officials from the Department of Commerce summoned to Capitol Hill for the first of a series of hearings at which opponents will press for its elimination.

Industry leaders have urged Congress to ensure that the trial is fair and to assess the programme on its merits. But recent Republican rhetoric, as well as earlier, highly partisan debates in the House of Representatives, have branded it as 'industrial policy', to which the new majority in Congress is strongly opposed.

Ron Brown, the commerce secretary, Mary Good, his under-secretary for technology, and Arati Prabhakar, director of the National Institute of Standards and Technology (NIST), which is responsible for running the ATP, were expected to offer an energetic defence of the programme at a hearing of the science, technology and space subcommittee of the Senate Commerce Committee, which was due to be chaired by Senator Conrad Burns (Montana) on Tuesday (31 January).

The Clinton administration has expanded funding for the programme, which helps industrial companies with pre-competitive research and development projects by paying half their costs, from $\$ 68$ million in 1993 to $\$ 199$ million in 1994 and $\$ 431$ million this year.

Such increases have made ATP by far the fastest-growing element in a federal science and technology budget that has remained flat overall at around $\$ 73$ billion a year - and an obvious target for Republi- can cuts. "It's probably the most vulnerable programme in science and technology," says David Goldston of the Council on Competitiveness, a centrist Washington think-tank.

Republican opponents, led by Robert Walker (Republican, Pennsylvania), chairman of the House Science Committee,

\section{Light work: ATP projects include use of hologram technology for fibre optics.}

have singled out the ATP for attack since last November's elections. Staff members say that the main issue is whether the programme should be severely curtailed, or closed altogether.

But Prabhakar said last week that her own conversations with congressmen were "going very well" and that the programme still retained a measure of bipartisan support. "We've heard a lot of rhetoric from people that don't know anything about how the programme works," she says. "My concern is to make sure the facts are on the table."

The programme, Prabhakar points out, began under the Bush administration after years of effort by industrial groups and government officials to decide how govern- ment could best help US industry with technological innovation. "ATP was designed on the basis of literally decades of false starts, with lots of smart people thinking about how to make it a really effective investment," says Prabhakar.

Its fate, she concedes, now rests with the willingness and ability of those whom ATP is supposed to benefit to lobby on its behalf. "The real issue will come down to whether industry thinks these are the right programmes."

Although the 1988 authorization of the programme and its first money - $\$ 10$ million in 1990 - were both driven by what was then a Democrat-dominated Congress, the programme's strongest early sponsor was Don Ritter, a since-defeated Republican Congressman from Pennsylvania. D. Allan Bromley, Bush's science adviser, became an enthusiastic proponent of ATP.

Bromley, now dean of engineering at Yale University, Connecticut, says that the ATP deserved to be expanded rapidly on the basis of its early performance. "Its first year was a great success," he says. "The fundamental problem is that the Clinton administration chose to make it a showpiece of their industrial policy." Bromley takes a more sanguine view than most of the prospect for ATP's survival. "When the dust settles, funding will be cut back somewhat but the programme will remain".

Even some of ATP's supporters feel that it was allowed to grow too quickly. The administration made a mistake in expanding ATP so fast, says William Morin, director of technology policy at the National Association of Manufacturers (NAM), a powerful lobby group. "It hadn't been around long enough to establish a track record."

NIST has plenty of case studies to talk about, but no real economic data on its success. Prabhakar says it will take 10 or 15 years for such data to emerge, and NIST has therefore had to use "short-term impacts", such as new business alliances and participants' impressions, to assess the programme. The NAM and other industry groups still support the Advanced Technology Program, and Morin says Congress should assess its effects "rather than subjecting it to some sort of ideological litmus test".

Last year, Clinton proposed the further expansion of the ATP to $\$ 540$ million in 1996 and $\$ 770$ million in 1997. His 1996 budget proposal, due to be published next week, may aim lower: the real budget, set by Congress over the summer, much lower still. Morin worries that there will be no real discussion of technology policy in the process. "We ought to go about this in a much more measured way," he says. 